\title{
110 Children with Coeliac Disease, 1950-1969
}

\author{
WINIFRED F. YOUNG* and ELIZABETH M. PRINGLE \\ From the Department of Gastroenterology, Queen Elizabeth Hospital for Children, London
}

\begin{abstract}
Young, W. F., and Pringle, E. M. (1971). Archives of Disease in Childhood, 46, 421. 110 children with coeliac disease, 1950-1969. 110 children with coeliac disease investigated over a period of 19 years are presented in 2 groups, 74 children presenting under 4 years and 36 over 4 years.

Sixty per cent of the older children showed extreme stunting of growth, while $28 \%$ in the younger group at referral were on or below the 3 rd centile. $75 \%$ of the younger children were anaemic as compared with over $90 \%$ of the older children.

Since 1952 all patients have been treated with a gluten-free diet, but in acute cases fluids only were allowed until dilatation of the small bowel had subsided. Thereafter, a low-fat-milk, and gluten-free diet was introduced in easy stages. Nearly all the younger children showed a good response to treatment, and an average weight gain of $1.6 \mathrm{~kg}$ was recorded 2 months after treatment had begun. There was no clinical evidence of lactase deficiency.

Relapses occurred in every child who had returned to a gluten-containing diet for any length of time. In younger children symptoms soon became apparent, but in the older group symptoms were sometimes delayed for months-or even years. Methods for detecting such subclinical relapses are described.

Forty-four children were followed up for periods of 8 to 19 years. 20 children who remained on a gluten-free diet gained weight, grew normally, and had no complications. The remainder, who did not, developed suboptimal growth and chronic ill health and were prone to diarrhoeal attacks, iron deficiency, and megaloblastic anaemia. 2 developed dermatitis herpetiformis. One had a crisis at pregnancy.

Reasons are given for recommending a life-long gluten-free diet.
\end{abstract}

The aetiology of the clinical entity 'the coeliac syndrome', whose manifestations were fully described by Gee (1888), Still (1918), Parsons (1932), and others, remained obscure until 20-25 years ago. Though astute clinical observation led these early physicians to treat the diarrhoea effectively by withdrawal of fatty and farinaceous foods, and some of the nutritional sequelae by mineral and vitamin supplements, they expected recurring exacerbations of the alimentary symptoms and knew that the long-term prognosis for growth and development would be poor. In 1947 Andersen, and in 1949 Sheldon, drew attention to the role of starchy foods as the precipitating factor of the malabsorption, while the Dutch workers pin-pointed particular cereals (Dicke, 1950; Dicke, Weijers and van de Kamer, 1953) and found that gluten, the protein fraction of wheat, was the offending substance.

\footnotetext{
Received 12 March 1971.

$\star$ Died May 1969.
}

They showed, and others confirmed, that withdrawal of this substance allowed the bowel to function normally, so that the serious consequences of longstanding malabsorption due to intolerance should no longer be seen. There are other causes of chronic diarrhoea in infancy which may be associated with the clinical features of the 'coeliac syndrome' and which must be excluded before a diagnosis of gluten enteropathy is made. It seems preferable to abandon labelling these cases until after more exact diagnosis and then to use the term gluten enteropathy for proven cases, which will help to emphasize their need to avoid gluten- containing foods throughout life.

This paper describes the findings in a consecutive series of cases in which the diagnosis has been fully established either at entry to the series or later when gluten-containing foods were being ingested. The investigations included those for malabsorption: (1) demonstration of malabsorption 
by examination of stool output; (2) exclusion of other malabsorption syndromes such as cystic fibrosis; (3) demonstration of typical alimentary findings by radiology; and (4) demonstration of jejunal mucosal atrophy at biopsy-reserved for cases with strong presumptive evidence already. Investigations for nutritional sequelae: (1) assessment of weight, height, and skeletal age in relation to chronological age; and (2) blood examination for anaemia, hypoproteinaemia, and rickets.

Treatment was at first directed to correcting severe alimentary disturbances and their nutritional sequelae, as in other diarrhoeal states. The longterm management was centred upon teaching the mothers to use gluten-free products in the family cooking as far as possible, so that the children could easily accept the minor restrictions necessary to ensure optimal health.

\section{Material}

The series consists of 110 children studied at the Queen Elizabeth Hospital between 1950 and 1969 (Fig. 1). 103 had presented with an alimentary episode

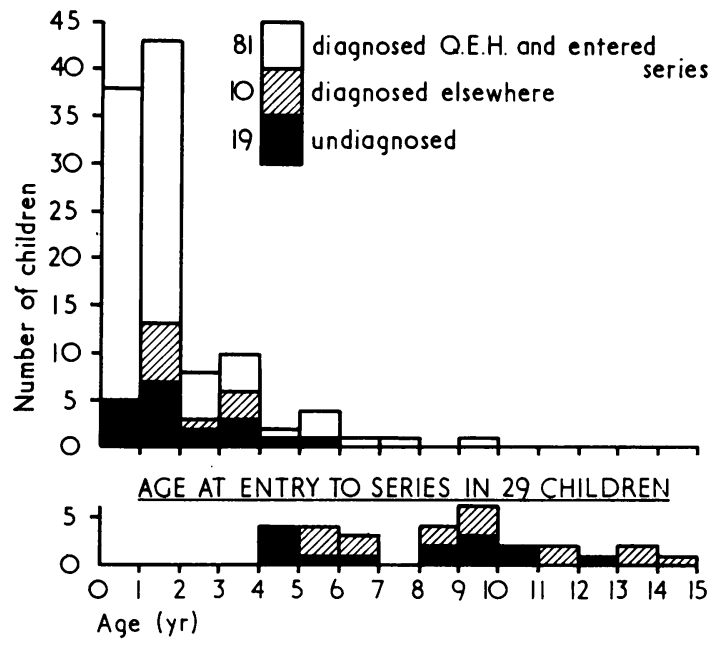

FIG. 1.-Age at first episode in 110 children; age at entry to series in 29 children.

before, and 3 after, 4 years of age; the remaining 4 presented as growth failure. 81 (74 of the younger and the 7 older) were diagnosed and entered the Queen Elizabeth Hospital series for treatment at once, while 10 of the other 29 had been recognized to be suffering from the coeliac syndrome during the first alimentary episode, but before the importance of withdrawing gluten was appreciated. They had improved on restricting the intake of fat, and sometimes of starch, for variable periods, and entered the series subsequently, many of them in relapse. The remaining 19 children had not been recognized at the time of their first episodes, but 5 had been diagnosed during later alimentary episodes ( 2 aged less than 4,1 aged 4 and 2 aged 6 years) before they entered the series for treatment. The inset of Fig. 1 shows the ages at which these children, and also the 10 diagnosed at their first episode, entered the series for treatment.

\section{Methods}

Since alimentary disturbances of varying severity result from gluten intolerance, early recognition of this aetiology depends upon obtaining a careful dietary history from cases which have no evidence of infection or gross anatomical abnormality of the bowel likely to be causing the symptoms.

\section{Alimentary investigation}

(a) Stool fat output. Initial fat balance studies were carried out in hospital, the diet being introduced 2 days before the collection began and continued for the period of collection without interruptions for other investigations. Meals were as similar as possible to the child's recent home diet, and contained a minimum of $50 \mathrm{~g}$ fat daily for children under 1 year and $75 \mathrm{~g}$ for older children; the exact fat content was estimated by analysis of aliquots. Stools were collected for 5 days and carmine markers were given to mark the beginning and end of this period. Latterly the method of Baldwin et al. (1962) was used.

Apart from the practical difficulties, enhanced by diarrhoea, of obtaining a complete stool collection from young children, the conditions of a number of the more severely affected cases deteriorated into crisis when 'forced' feeding with relatively high amounts of fats was prescribed. For follow-up examination it was often found possible to arrange a stool collection at home. In these cases the fat intake cannot be measured exactly, but this is not essential provided adequate amounts are taken and the parents asked to make sure that a full fat gluten-free diet is given throughout the collection. The fat content was estimated as described by van de Kamer, Huinink, and Weijers (1949).

(b) Radiological examination. The method of $x$-ray procedure and the interpretation of the results is described by Haworth et al. $(1967,1968)$.

(c) Jejunal biopsy. Confirmatory, though not completely specific, evidence that malabsorpition was due to gluten intolerance was obtained by finding the typical abnormality of the duodenal or jejunal mucosa at biopsy.

All biopsies are carried out under hospital supervision, the child being admitted the day before and remaining the night after biopsy. $\mathrm{He}$ is starved overnight but may have clear fluids till the start of the biopsy at 9.30 a.m. the following morning. However, if this procedure is to be undertaken safely and successfully in acute cases it is very important to wait until the clinical condition of the child has improved. In our experience, the findings have still been positive as long as 3 to 4 weeks after gluten-containing foods have been with- 
drawn, but the clinical condition of the child often improves sufficiently much sooner than this. The procedure must always be delayed until the gross abdominal distension and severe alimentary disturbance have subsided, and this is hastened by withholding all milk and solid food, and giving glucose and electrolyte mixtures and simple purées, as for other diarrhoeas. It is worth while regrading to simple feeds even in the less severely affected cases. If sedation is required, rectal paraldehyde $0.5 \mathrm{ml} / \mathrm{kg}$ with equal parts of arachis oil is given initially and throughout the proceedings, as required, in all children under 5 years, except babies under 9 months who will cheerfully suck down a capsule at the same time as a feed of glucose and saline. Children over 5 are given large doses of methylpentynol the day before the procedure, and on the morning of the biopsy. In this age group only, the throat is sprayed with $1 \%$ amethocaine before introducing the capsule.

The first biopsies were carried out with the Shiner Tube (Shiner, 1956a,b) at the Central Middlesex Hospital by Dr. Margot Shiner herself and, later, her technique was followed at this hospital. Since 1961, the adult Crosby capsule (Crosby and Kugler, 1957) has been used on all children over 1 year and sometimes in younger ones. In addition, various smaller modifications of this capsule have been tried during the past 2 years, and the Watson paediatric capsule (Read et al., 1962) fitted with an Odman-Ledin Red No. 1 arterial catheter is currently being used for babies under 1 year. After swallowing the capsule into the stomach, the child is arranged in a semiprone position on its right side, and the tube allowed to be carried along by peristalsis. Progress is encouraged by injecting $0.7 \%$ saline into the stomach and less often by judicious manipulation. The position of the capsule is confirmed by a single AP supine $x$-ray. Not more than three such pictures are allowed and, if the capsule fails to reach the jejunum a duodenal biopsy is taken or the procedure abandoned.

The specimen is examined under the dissecting microscope to determine whether villi are present and, if so, their size and shape as described Booth et al. (1962). A portion of the specimen is set aside for enzyme studies, and the remainder quickly frozen and stained to produce sections for histological studies. Not only is an immediate diagnosis thus available, but a check is provided on the depth of the incision, and all food is withheld until this is seen to be satisfactory.

In gluten enteropathy intestinal mucosal changes include absence of villi, disorganized epithelium, and round-celled infiltration of the lamina propria (Paulley, 1954; Sakula and Shiner, 1957). If the child has been on a gluten-free diet for a period, the picture may be modified and show some regeneration of the villi, and this is taken into account and evaluated with the history when the child has been tentatively diagnosed elsewhere. Enzyme studies were carried out by the method of Burgess et al. (1964) on all samples of mucosa obtained since 1966 .

\section{Nutritional status}

(a) Weight, height, and skeletal age, Weight and height standards were taken from Modern Trends in Paediatrics (Tanner, 1958) and from charts prepared by J. M. Tanner and R. H. Whitehouse. Skeletal ages have been assessed from the Radiographic Atlas of Skeletal Development of the Hand and Wrist (Greulich and Pyle, 2nd edition).

(b) Haemoglobin levels. The haemoglobin levels were assessed by photoelectric determination by the oxyhaemoglobin method, and the normal levels of children from birth to 4 years have been taken from M.R.C. Report No. 252 (1945).

(c) Serum proteins. The serum proteins were estimated by the micro-Kjeldahl method and the normals have been taken from M.R.C. Report No. 296 (Levin et al., 1959).

\section{Results}

Findings at entry to series. The findings at entry to the series have been assessed for two groups divided according to age; 76 younger children under 4 years and 36 older children between 4 and 14 years.

All the children in the younger age group and most of those in the older were suffering from overt alimentary symptoms, but a few of the latter presented instead with short stature or a previous history of an illness like 'coeliac disease'.

In this report an alimentary episode signifies a period during which disorder of alimentary function was severe enough for medical advice to be sought. It was acute if considered to warrant treatment in hospital and otherwise subacute, though the patient might have been admitted to hospital for investigation. A few of the older children had a history of having had abnormal stools for years, but were not suffering from an exacerbation and their alimentary disorder is labelled insidious.

Younger children. The first episodes in nearly all (61 of 74) were acute. It has been possible to study the history of alimentary symptoms culminating in these 74 episodes from the records of only 63 of the children. Nearly twothirds (38 of 60 ) were said to have ingested glutencontaining cereals before 3 , and all but 4 before 6 months of age. Fig. 2 shows the interval from age of ingestion to onset of symptoms. This was between 3 and 6 months in more than half (37 of 60) of the children. It was never less than 1 month and much longer in some infants, being over a year (13-20 months) in 5 of them. Fig. 3a shows that 25 of the 63 children had their first symptom before 6, and 41 (two thirds) before 9 months of age. Fig. $3 \mathrm{~b}$ shows the age at the first episodes ( 50 acute and 13 subacute) in the same group of children when they entered the series for diagnosis, 


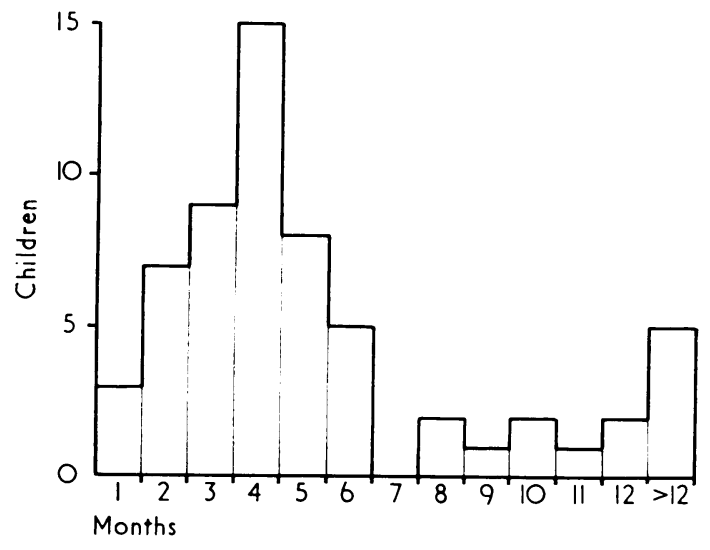

FIG. 2.-Time interval between first impact of glutencontairing cereal and first symptom.

and Fig. 4 the interval from the first symptom to diagnosis.

Many infants suffer from transitory alimentary disturbances due to infection, which subside after temporary withdrawal of milk feeds. Intolerance of gluten cereal is therefore not suspected until symptoms recur or persist, which explains the delay to diagnosis. More often the aetiology is not considered until the onset of a more acute episode follows the chronic symptoms.

Table I shows the incidence of the common alimentary symptoms and the consequences of nutrition for these younger children. All had abdominal distension in association with changes in the stool output, and this is an important early diagnostic feature. Occasionally it may progress to mimic intestinal obstruction, which is usually easily excluded from the history and by $x$-ray examination. However, one of our patients had had a laparotomy preceding referral to this series and there are hospital records of other cases in whom this was considered necessary. symptoms of failure to thrive, distension, abnormal
The majority of cases presented with the classical

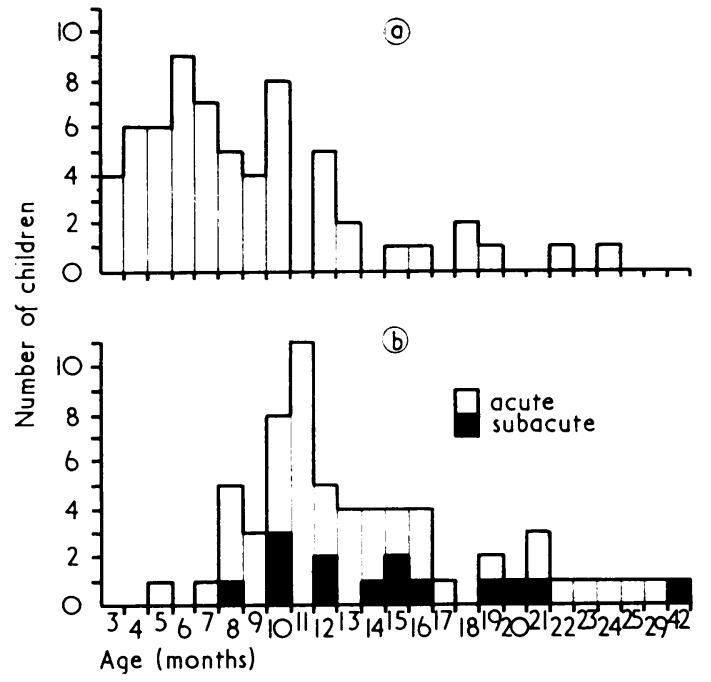

FIG. 3a.-Age at first symptom in 63 children under 4 years.

FIG. 3b.-Age at entry of 63 children under 4 years.

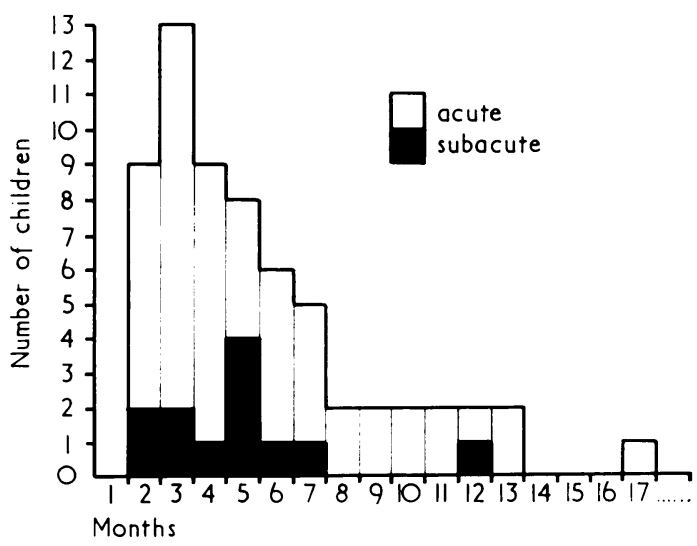

FIG. 4.-Time interval between first symptom and diagnosis in 63 children under 4 years.

TABLE I

History of Symptoms Preceding Entry to Series in 74 Children Under 4 years of Age

\begin{tabular}{|c|c|c|c|c|c|c|c|}
\hline \multicolumn{6}{|c|}{ Alimentary } & \multicolumn{2}{|c|}{ Nutritional } \\
\hline \multicolumn{3}{|c|}{ Stools } & \multirow{2}{*}{$\begin{array}{l}\text { Abdominal } \\
\text { Distension }\end{array}$} & \multirow{2}{*}{ Anorexia } & \multirow{2}{*}{ Vomiting } & \multirow{2}{*}{$\begin{array}{l}\text { Failure to } \\
\text { Gain or } \\
\text { Slow Gain }\end{array}$} & \multirow{2}{*}{$\begin{array}{c}\text { Loss } \\
\text { of } \\
\text { Weight }\end{array}$} \\
\hline Abnormal & Diarrhoea & Crisis & & & & & \\
\hline $100 \%$ & $58 \%$ & $13 \%$ & $100 \%$ & $80 \%$ & $70 \%$ & $100 \%$ & $66 \%$ \\
\hline
\end{tabular}


stools, and anorexia, but occasionally the pattern of symptoms was atypical.

Fig. 5 illustrates the wide variation in the preceding course of the disease in a few of the infants entering the series at their first episode.

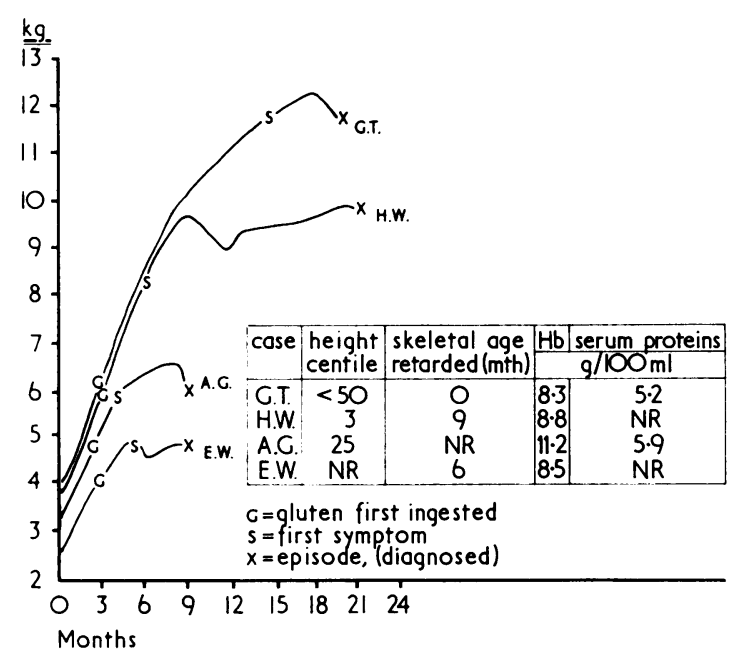

FIG. 5.-Varied history in 4 children.

Gluten-containing cereals were said to have been given to these 4 children around 3 months of age, yet 3 developed alimentary symptoms or failure to thrive within 3 months, whereas the other (G.T.) appeared to have been unaffected until 15 months of age, when his appetite deteriorated and he stopped gaining. There were no other alimentary symptoms until he was 17 months, when he lost weight, with diarrhoea and occasional vomiting, and at this time abdominal distension was noticed suggesting the diagnosis.

Among the 3 with earlier symptoms, 1 (H.W.), despite typical stools, gained normally for 3 months; she later lost weight and became anaemic at 1 year. Though anorexic, she subsequently gained slowly and the eventual development of abdominal distension at 19 months led to the correct diagnosis.

E.W. presented at 5 months with severe anorexia, vomiting, and failure to thrive. The motions were normal, and investigations for metabolic or anatomical disorders were negative. By 9 months of age when abdominal distension first appeared she had signs of severe malnutrition.

In A.G. the symptoms developed more typically with abdominal distension at 4 months and diarrhoea at 5 months associated with poor weight gain. By 8 months he had anorexia and a diarrhoeal crisis developed in hospital after attempts were made to improve his nutrition.

Some of the children had been at even greater risk from delay in diagnosis, when very acute alimentary symptoms supervened on chronic malnutrition due to prolonged malabsorption.

K.M. was fed cereals at 3 months and developed greasy stools at 4 months. By 9 months on a mixed diet, though physically well, she vomited occasionally after meals. By 14 months she was vomiting every day, though her appetite remained good. Milestones were reached normally, but at 1 year she stopped standing up and became listless. At 16 months she became miserable and was admitted to hospital with frequent diarrhoea. Coeliac disease was suspected but after 10 days on a gluten-free diet with no improvement the diagnosis was abandoned and she was transferred to this hospital aged 1 year 9 months -17 months after the first symptom had appeared. She had gross wasting, gross abdominal distension, and anaemia $(\mathrm{Hb} 7 \cdot 0 \mathrm{~g} / 100 \mathrm{ml})$, and was in crisis, necessitating intravenous therapy and blood transfusion.

Fig. 6 shows (a) G.T. aged 17 months, (b) E.W. aged 10 months, and (c) K.M. aged 21 months at presentation.

\section{Alimentary investigation}

(a) Stool fat output. Of 40 children examined, 1 excreted $3.3 \mathrm{~g}$ daily and all the rest between 4 and $26 \mathrm{~g}$. These results compare with Andersen and di Sant' Agnese (1953) who found that the upper limit of normal was $3 \mathrm{~g}$ daily in 42 children from 1 to 5 years, and Anderson (1966) who gave a figure of $4.6 \mathrm{~g}$ per day provided an adequate amount of dietary fat was ingested.

In the early days of the survey, the more exact diagnostic tests had not been worked out and it was then regarded as obligatory to demonstrate malabsorption. It was, however, found that increasing the intake of food for this purpose in children with severe bowel dilatation could provoke a serious exacerbation. In fact, 6 developed diarrhoeal crises, 3 of whom became dangerously dehydrated overnight. Critical appraisal of their suitability for a formal fat balance therefore became imperative before the investigation of subsequent cases. Table II shows that it was attempted in rather more than half, and achieved in about half the cases. Others had been partially investigated before admission to hospital by other methods and had shown a very high percentage of fat in the dry weight, while fat in the stool on microscopy was noted in several of the remainder. Demonstration of fat in the stool was not attempted in 12 


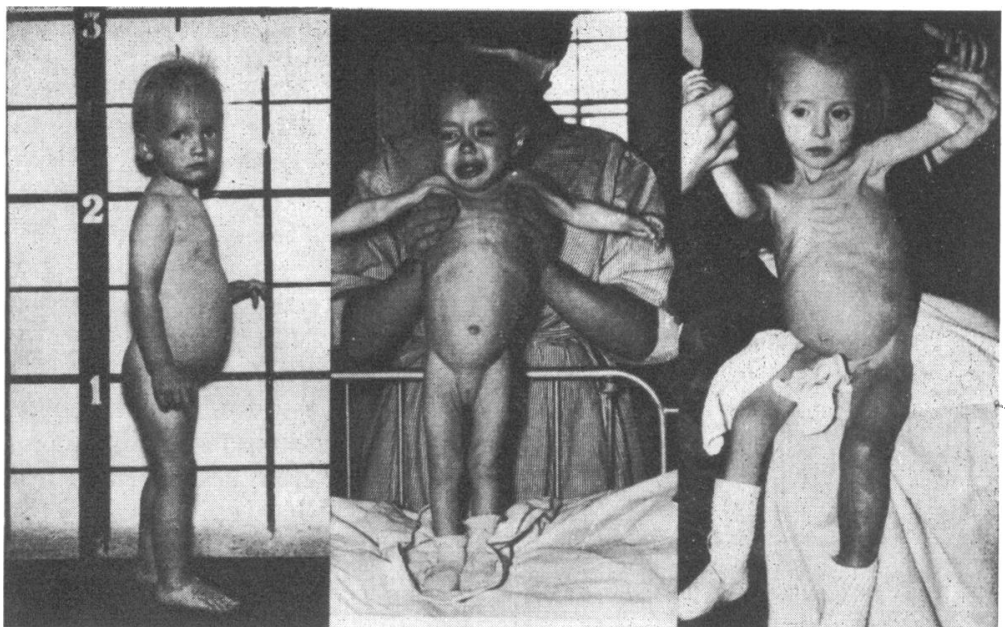

Fig. 6.-Types of presentation in 3 children under 4 years-left to right. (a) G.T. aged 17 months; (b) E.W. aged 10 months; (c) K.M. aged 21 months.

cases, in some because the stools were very loose and in others because they had already been given only clear fluids or fat-free milk as symptomatic treatment.

(b) Radiological examination. Table II shows that most of the children in acute episodes had dilatation with fluid levels indicating the imminent risk of diarrhoeal crisis if treatment had been delayed. Details of $x$-ray findings are described elsewhere (Haworth et al., 1968).

(c) Jejunal biopsy. A biopsy was carried out at the time of referral in 42 children and in every case complete villous atrophy was found. In 9 children a biopsy was obtained during initial treatment of the illness, 1 to 4 weeks after withdrawal of gluten from the diet, and consequently the mucosa-though still abnormal-showed some signs of regeneration. In 18 children biopsy confirmation was obtained later, either because they were too ill at the onset, parental consent was refused, early biopsy failed, or the procedure was not available at the time they entered the series.
It was not possible to obtain biopsy confirmation in 5 children, all of whom recovered completely on a gluten-free diet. 4 relapsed on returning to a gluten-containing diet and 1 child, who has only just regained full health on a gluten-free diet, will be challenged later.

Enzyme activity. Forty-five jejunal specimens and 4 duodenal were examined. It was found that lactase, maltase, palatinase, and sucrase were diminished in every case, the lactase deficiency being most marked (Levin, 1969).

\section{Nutritional status}

(a) Weight, height, and skeletal age. Fig. 7 shows the weights and heights of children diagnosed under the age of 4 years. Two-thirds of the children were below the 3rd centile for weight and none was above the 50th. Almost all were below the 50th centile for height and $28 \%$ were on or below the 3rd. The skeletal age of all the

TABLE II

Evidence of Malabsorption on Admission in 74 Children Under 4 years of Age

\begin{tabular}{|c|c|c|c|c|c|c|c|c|c|c|}
\hline \multirow{3}{*}{$\begin{array}{l}\text { Clinical } \\
\text { State }\end{array}$} & \multirow{3}{*}{ No. } & \multicolumn{5}{|c|}{ Steatorrhoea } & \multirow{2}{*}{\multicolumn{4}{|c|}{$\frac{X \text {-ray Findings }}{\text { Small bowel Dilatation }}$}} \\
\hline & & \multicolumn{3}{|c|}{ Fat Balances } & \multirow{2}{*}{$\begin{array}{c}\text { Stool } \\
\text { Microscopy }\end{array}$} & \multirow{2}{*}{$\begin{array}{c}\text { High } \\
\text { Percentage } \\
\text { Dry } \\
\text { Weight }\end{array}$} & & & & \\
\hline & & Completed & Unsatisfactory & $\begin{array}{l}\text { Not Attempted } \\
\text { (-too ill, etc.) }\end{array}$ & & & $\begin{array}{c}+++ \\
\text { (fluid levels) }\end{array}$ & ++ & 0 & N.R. \\
\hline $\begin{array}{l}\text { Acute } \\
\text { Subacute }\end{array}$ & $\begin{array}{l}60 \\
14\end{array}$ & $\begin{array}{r}30 \\
9\end{array}$ & $\frac{8}{-}$ & $\begin{array}{r}10 \\
2\end{array}$ & $\begin{array}{l}6 \\
2\end{array}$ & $\begin{array}{l}6 \\
1\end{array}$ & $\begin{array}{r}41 \\
4\end{array}$ & $\begin{array}{r}9 \\
10\end{array}$ & & 10 \\
\hline
\end{tabular}




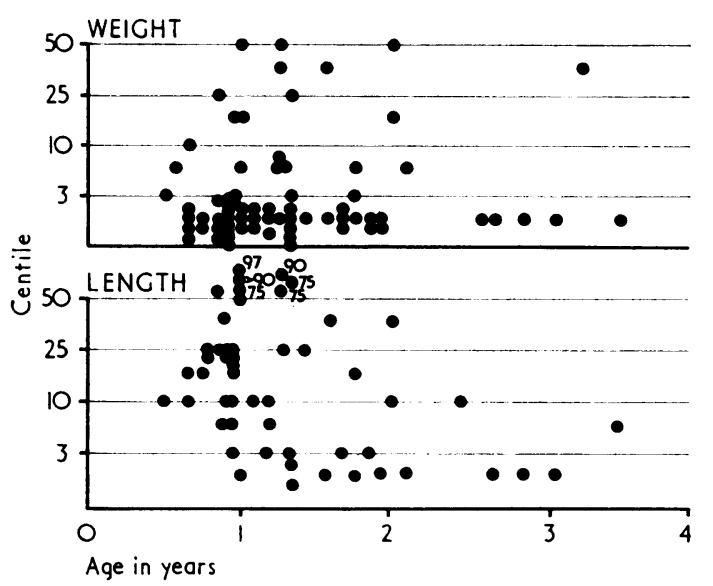

FIG. 7.-Lengths in 54, and weights in 74 children entering the series under 4 years.

children examined in this age range was assessed as normal or below for their chronological age, indicating growth retardation. Of 43 children examined, 14 had no retardation and 15 were retarded more than 6 months. Of the latter, 5/19 were aged 0-1 year, 8/17 1-2 years, and 2/6 2-3 years.

(b) Haemoglobin levels. Fig. 8 shows the $\mathrm{Hb}$ levels of 72 children on entry, 54 of whom were below the normal limits (72\%). Other investigations showed that these children had a hypochromic anaemia. Table III shows the $\mathrm{Hb}$ level of 36 children at entry and during the following 4 months. Even when the $\mathrm{Hb}$ was more than $11 \mathrm{~g}$ originally, there was in almost all children a definite fall during the early months of treatment unless iron supplements had been given.

(c) Serum proteins. Fig. 9 shows the serum protein levels of 43 children taken at an early stage in their first admission. More than half were below normal, and 11 of the children were in crisis, 10 of whom had a level of $5.5 \mathrm{~g} / 100 \mathrm{ml}$ or less, and 1 of $5.9 \mathrm{~g} / 100 \mathrm{ml}$. The albumin fraction was found to be outside the lower limit of normal in all but 1 of 12 children tested and below $4 \mathrm{~g} / 100 \mathrm{ml}$ in 6 of them. The globulin fraction was normal in all cases.

Older children. The clinical manifestations in these 36 children varied much more than in the younger age group, on account of the longer duration of their malabsorption. Though earlier severe episodes (22 acute) had occurred in 29 of these children, the diagnosis of coeliac disease had not been made in 14 of them (Fig. 1). 2 had had no clinical sequelae apparent to their parents, while 3 others had been aware of only minimal alimentary disturbances. Nevertheless 3 had had severe exacerbations before 3 years of age, 1 of whom became severely malnourished and developed rickets, and 6 had had persistent alimentary symptoms, 3 with and 3 without exacerbations of diarrhoea.

Seven of the 10 diagnosed at their first episode had had prolonged hospital admissions and 2 had developed rickets. 4 of the 5 diagnosed later were, in fact, suffering from acute episodes. Many of these cases were treated before 1950, when it was customary to grade the diets from low carbohydrate and fat to starch-free meals. Despite apparently effective early treatment, only 5 had continued on any restriction of starchy foods, but their diets were not specifically gluten-free. Consequently, the incidence of relapse was very highonly 4 of 6 who had remained on partial treatment escaping. The case histories and appearances at entry to the series of several of these children,

TABLE III

Haemoglobin Levels in 36 Children Under 4 years at Entry and During the Following Months, With/Without Initial Iron Treatment

\begin{tabular}{|c|c|c|c|c|c|c|c|c|c|}
\hline \multirow{2}{*}{$\begin{array}{c}\text { Hb } \\
\text { Estimation } \\
\text { At Entry }\end{array}$} & \multirow{2}{*}{$\begin{array}{c}\begin{array}{c}\text { No. of } \\
\text { Children }\end{array} \\
36\end{array}$} & \multicolumn{4}{|c|}{$11 \mathrm{~g}$ or more ( 19 children) } & \multicolumn{4}{|c|}{ Less than $11 \mathrm{~g}$ (17 children) } \\
\hline & & \multicolumn{2}{|c|}{ Untreated } & \multicolumn{2}{|c|}{ Treated } & \multicolumn{2}{|c|}{ Untreated } & \multicolumn{2}{|c|}{ Treated } \\
\hline $\begin{array}{l}\text { At } 1 \text { month } \\
\text { At } 2 \text { months } \\
\text { At } 3 \text { months } \\
\text { At } 4 \text { months }\end{array}$ & $\begin{array}{r}14 \\
11 \\
6 \\
5\end{array}$ & $\begin{array}{l}7 \\
4 \\
2 \\
2\end{array}$ & $\begin{array}{l}2 \\
1\end{array}$ & & 1 & $\begin{array}{l}2 \\
2 \\
1\end{array}$ & 1 & 1 & $\begin{array}{c}3 \\
\text { (2 transfusions) } \\
1 \\
3 \\
3\end{array}$ \\
\hline
\end{tabular}




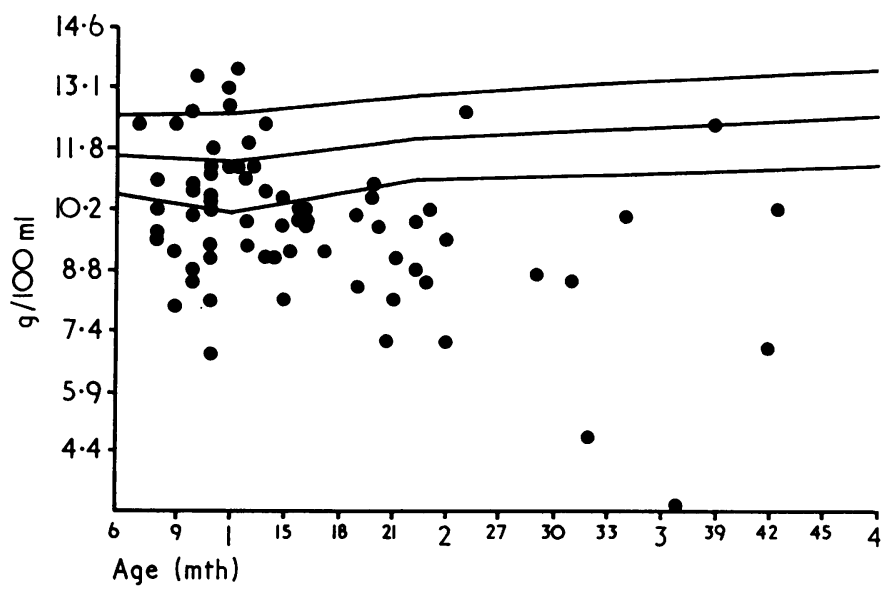

FIG. 8.-Haemoglobin levels at entry in 72 children under 4 years.

to show the wide variation in their subsequent course, follow.

\section{Types of presentation}

(a) Subclinical. C.M. was discovered at 4 years 3 months on routine examination when her younger sister was diagnosed. She had had an acute episode in the first year of life, and a subacute one at $2 \frac{3}{4}$ years, since when there had been no obvious symptoms. She was well nourished, but in hospital was found to have loose bulky stools and abdominal distension. Stool collection showed an excretion of $15 \mathrm{~g}$ fat/day and an $x$-ray examination demonstrated small bowel dilatation with fluid levels (Fig. 10a)

(b) Insidious. D.S. entered the series at 9 years 10 months. She had a subacute episode at $4 \frac{1}{2}$ years and a recent history of loose bulky stools, anorexia, vomiting, and abdominal distension.
She was extremely stunted and bone maturation was much delayed. Faecal fat excretion was 3.6 $\mathrm{g}$ per day (the fat input was small owing to anorexia) and $x$-ray examination showed small bowel dilatation (Fig. 10b).

(c) Nutritional. S.B. entered at 7 years 7 months. The onset was insidious; apart from occasional vomiting, there were no symptoms though he had always had a poor appetite. Bowels were constipated. He had been investigated for growth failure at 6 years and had not grown or gained for 4 years. In hospital, his stools became large and offensive when gluten intake was encouraged. Faecal fat excretion was $10.5 \mathrm{~g} /$ day. $X$-ray examination showed small bowel dilatation with fluid levels (Fig. 10c).

(d) Acute. J.K. entered at 6 years 7 months. $\mathrm{He}$ had a history of failure to thrive at 13 months and diarrhoea followed by bulky offensive stools

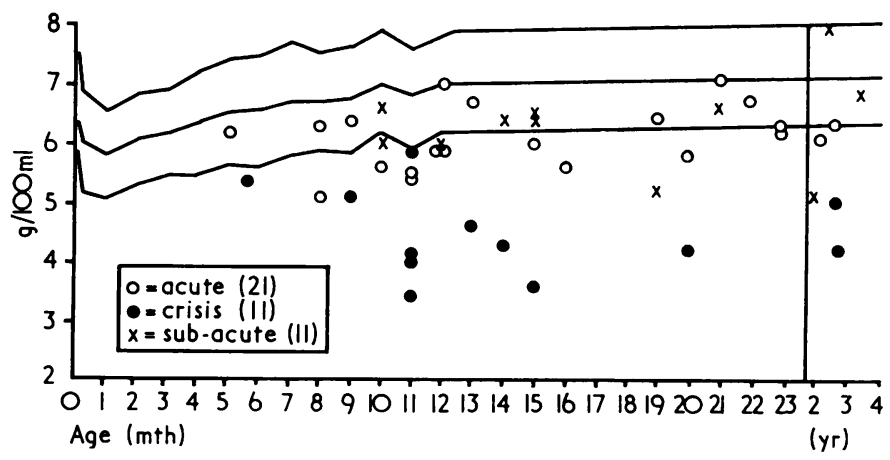

Fig. 9.-Serum protein levels at entry in 43 children under 4 years. 


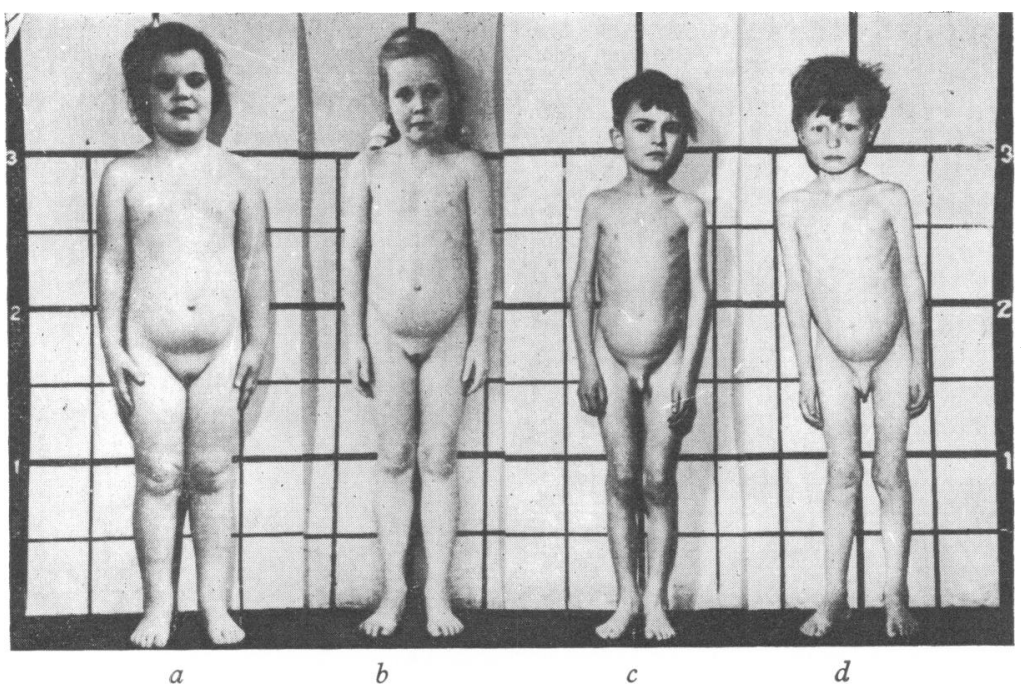

FIG. 10.-Types of presentation in 4 children over 4 years-left to right. (a) Subclinical, C.M. aged 4 years 3 months; (b) Insidious, D.S. aged 9 years 10 months; (c) Nutritional, S.B. aged 7 years 7 months; and (d) Acute, J.K. aged 6 years 7 months.

from 2 years of age, but the diagnosis was not made until 4 years 2 months. Despite partial treatment at various hospitals, he became listless and lost weight. When admitted, he was oedematous and had gross malnutrition. He was very wasted and hardly able to walk. Faecal fat excretion was $12.5 \mathrm{~g} /$ day and $x$-ray examination showed small bowel dilatation (Fig. 10d).

Fig. 11 shows the clinical state according to age of the 36 older children on entry to the series. Though 6 were symptom free and 4 complaining of small stature only, on close inquiry all the latter gave a history of minor alimentary symptoms lasting

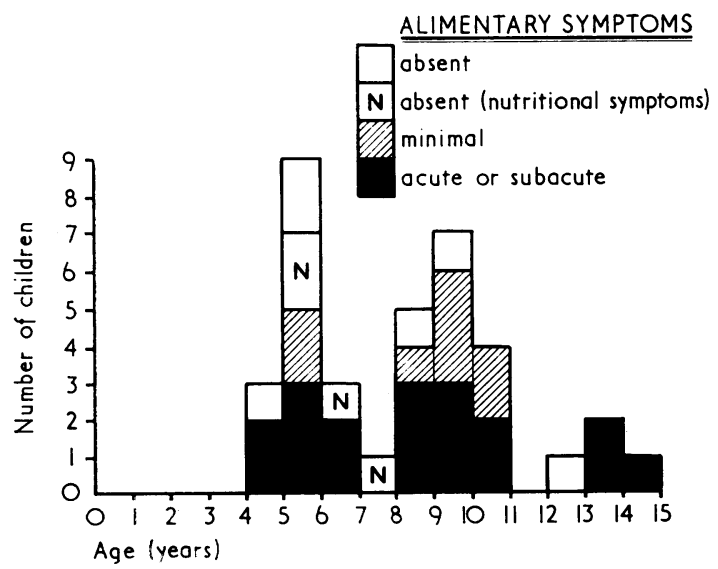

Fig. 11.-Mode of presentation of 36 cases over 4 years. for at least 3 years. Of these 10 supposedly symptom-free children, 4 had had bulky stools, 6 abdominal distension, and 7 anorexia. One was said to have had a ravenous appetite and 2 a history of vomiting. In the 26 children whose symptoms were predominantly alimentary, all, like the younger children, had abnormal stools and some had diarrhoea, $23 \mathrm{had}$ abdominal distension, 15 had anorexia, and 7 had vomiting. 4, however, had a large appetite.

\section{Alimentary investigation.}

(a) Stool fat output. The reintroduction of gluten for the purpose of the investigation resulted in little or no change in their clinical condition. However, investigations showed that the steatorrhoea and radiological findings were of the same order, and grossly abnormal, in the subclinical group who had not been complaining of alimentary symptoms, as in those in an active phase, many of whom were in clinical relapse. Daily fat excretion was measured in 34 children. 27 excreted $4.5 \mathrm{~g}$ $15 \mathrm{~g}$ per day, 4 excreted more than $15 \mathrm{~g}$ per day, and 2 were normal.

(b) Radiological examination. After stressing with gluten if necessary all the patients examined (31) showed dilatation of the small bowel; in 11 this was gross, in 17 moderate, and in 3 minimal only.

(c) Jejunal biopsy. A successful biopsy was 
achieved in 28 patients, 25 of whom showed complete and 3 partial villous atrophy. 9 biopsies took place at the onset and 19 at a later date. 17 of the latter were performed during a clinical or subclinical relapse due to a faulty diet and 2 during a planned gluten trial.

\section{Nutritional status}

(a) Weight, height, and skeletal age. Fig. 12 shows the weights and heights of the older children at entry to the series.

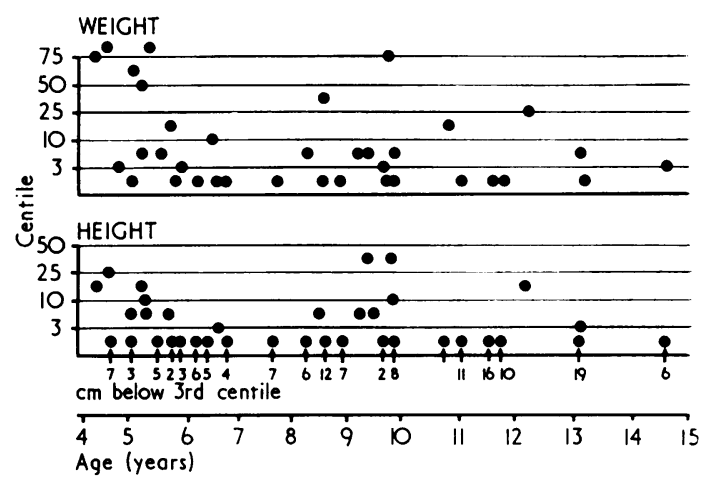

FIG. 12.-Heights and weights at entry in 36 children over 4 years.

The heights of 20 and the weights of 14 were below the 3rd centile and only 6 achieved a height above the 10th centile, while 10 had a weight above this.

Bone maturation was retarded by more than 1 year in 23 of 25 patients examined. In 6 the delay was more than 6 years.

(b) Haemoglobin levels. 33 patients had $\mathrm{Hb}$ levels below $11 \mathrm{~g} / 100 \mathrm{ml}$ and 6 of these levels were below $7 \cdot 4 \mathrm{~g}$. The other 3 were normal.

(c) Serum proteins. The total serum protein level at the onset was above $6 \mathrm{~g} / 100 \mathrm{ml}$ in all 27 patients examined and above $6 \cdot 8 \mathrm{~g}$ in 15 of them.

Treatment and early response. All the children were given gluten-free food. In most younger children 3 dietary stages were recognized. Acute cases were treated symptomatically by slowly regrading their intake of food from clear glucose electrolyte mixtures to low fat milk, either half-cream National Dried (for babies) or machine skimmed milk (Stage 1). A few children in crisis had needed to be rehydrated at first by giving fluids parenterally. As stools began to improve the calorie intake was boosted by the addition of mashed banana, pureed apples, vegetables, and lean meats. Starches were largely avoided (Stage 2). Only after 2-4 weeks on this regimen were solids introduced including gluten-free starch foods (Stage 3). If this diet was well tolerated, full fat milk was gradually reintroduced so that by the end of 2 months, with few exceptions, the only restriction was gluten. In the early stages, glucose was used exclusively as a sweetening agent.

Fifty-eight children under 4 years were treated in this way and the majority were beginning to improve by the second week, losing their irritability,

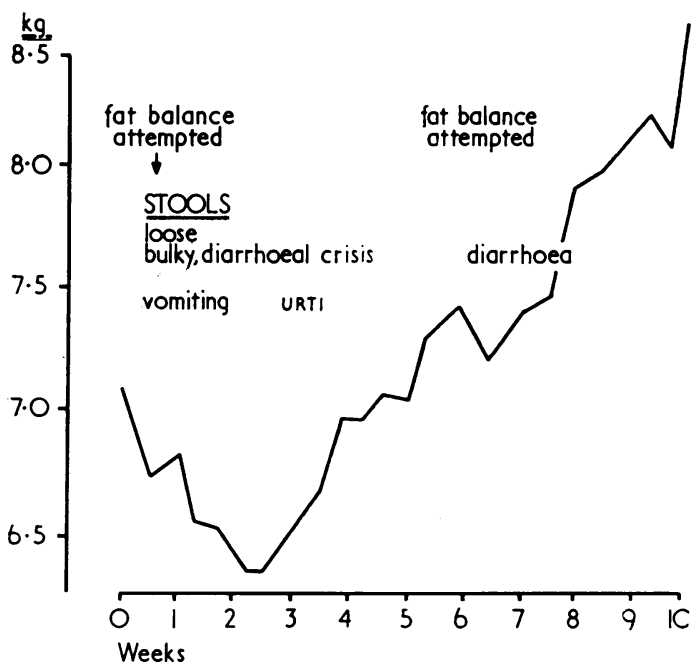

FIG. 13.-Weight chart showing a delayed response to treatment.

and becoming more cheerful. 56 of them had an average weight gain of $1.6 \mathrm{~kg}$ by 2 months. 3 children had had a salmonella and 3 a specific Esch. coli infection which had delayed their initial response and recovery. All but 1 of these, together with all the other children with initial delays, rapidly picked up weight with treatment, and by 2 months there was no difference in their weight gain as compared with children who had had a good steady response from the beginning. Of 2 children who did not gain satisfactorily until 3 months, 1 had been given gluten by mistake, and the other had a severe Esch. coli infection. Fig. 13 shows the weight chart of a child who was pushed into crisis by an attempted fat balance. This, together with an upper respiratory infection, contributed to his delayed weight gain.

Arthur et al. (1966) considers that there is a lactose intolerance in the early stages of coeliac 
disease which may last upwards of a year and they recommend a limitation of lactose during this period to obtain maximum weight gain. McNeish (1967), in a study of 24 children with coeliac disease, showed that 20 of them had no evidence of lactose intolerance and only 2 did not gain weight until lactose was removed from the diet. In the present series no clinical evidence of lactose intolerance was found.

During the early months of treatment, the stool output of 10 children under 4 years was re-examined after a period of treatment varying between 1 month ( 2 children) and 18 months ( 1 child); 4 of the remainder at 2 months and 3 at 3 months.

Only 1 (E.W., tested at 1 month) showed malabsorption and she and only 2 of 9 others examined had small bowel dilatation, 1 of whom had been given gluten by mistake. Fragmentation after flocculating meal was seen in 4 examined. Later examination of the stool output of these 10 patients on full fat gluten-free meals gave normal results within 2 years from the beginning of treatment. 2 exceptions who showed persistent steatorrhoea at 13 months and 14 months gave normal results at 21 months and 2 years respectively.

The stool output and radiological appearances were tested repeatedly in many more of the children early in the series than later, when the usual pattern of recovery had become familiar. Thus, results from 25 of the children showed normal stool output on full fat gluten-free feeding within 3 months in 3,3 to 6 months in 8,6 to 12 months in 8 , and 1 year to 18 months in 6 . In many, however, this response was only tested once, at a time convenient for stool collection, and a similar response might have been observed much sooner in many of the cases. In accordance with Haworth et al. (1968), none of the children with normal stool output had abnormal radiological findings.

Only a few in the older group of children (i.e. those in crisis) required such careful regrading of the diet. Most were started on a low fat, glutenfree diet, occasionally with purées for a few days, and as improvement occurred, so the amount of fat allowed was increased. Fat soluble vitamins were given to all patients until the fat intake was normal.

The response to treatment was less dramatic in this older group except for those presenting in an acute episode. This was to some extent accounted for by the children's (and parents') reluctance to institute a strict dietary regimen. However, 19 of the patients did have a gluten-free diet, though at least 5 of them were strict for only a relatively short period ( 3 months to 2 years).
In these patients the disease became quiescent as judged by results of investigations within 2 to 30 months of the start of treatment. Only 4 had normal results before 9 months elapsed.

Relapses. Relapses in the first 2 years of treatment in young children were frequently seen during intercurrent infections and responded readily to regrading the diet. Later, relapses were always due to eating gluten-containing foods. If symptoms were overt both parent and child were able to understand the necessity for reappraisal of the diet. In many cases, however, especially in older children, there were no symptoms. A subclinical phase of malabsorption associated with small bowl dilatation then persisted undetected for months or years. Such children were examined at regular intervals for signs of growth failure and malabsorption: many, but not all, grew more slowly and most showed progressive iron and folic acid deficiency.

Infrequent, serial radiological examinations of the abdomen were found of value in detecting the onset of small bowel dilatation. In such cases during the early days of the survey the children were investigated radiologically much more frequently than would be necessary or justified at the present time. $X$-ray findings were correlated with clinical laboratory data, and an analysis of the results has shown some interesting features already published (Haworth et al., 1968).

In nearly every case it was found that, whenever small bowel dilatation was present, steatorrhoea was also present and in those cases where it was not, steatorrhoea subsequently developed within a month or two. It also became evident that if the jejunum was dilated the ileum would also be dilated. In a follow-up over the years, therefore, it is only necessary to take 1 film at infrequent intervals to determine whether or not small bowel dilatation and, by inference, malabsorption, is present. Haworth et al. (1967) also made a study of the radiological measurements of small bowel calibre in normal subjects according to age, and found that these ranged from $12 \mathrm{~mm}$ at 6 months to $23.1 \mathrm{~mm}$ \pm 1.93 for adults. The figure for adults agrees with that found by Laws et al. (1963) who stated that a jejunal calibre measuring $25 \mathrm{~mm}$ or less is not dilated. When malabsorption is suspected, measurement of the small bowel provides an early indication of active disease.

C.H. was diagnosed at 8 years 10 months and put on a gluten-free diet. At 12 years 10 months she admitted reverting to a normal diet 9 months previously, eating about 3 or 4 slices of bread daily. 
She had no symptoms. Fig. 14a is an $X$-ray picture of the abdomen after micropaque, aged 12 years 10 months, and shows dilated bowel, the average calibre of which is $36 \mathrm{~mm}$ (normal $22.5 \mathrm{~mm}$ ). Thereafter she kept to a strict diet and a further $x$-ray at 14 years 4 months (Fig. 14b) showed normal small bowel measuring $23 \mathrm{~mm}$ in diameter. Unfortunately, the diet subsequently lapsed for a long period and she developed megaloblastic anaemia.

Late follow-up. Table IV shows 44 children who were followed up for a period of 8-19 years, many of them after attaining adulthood. They were classified as far as possible into those who had always kept to a strict gluten-free diet; those who had never had any restriction, except perhaps for a month or two after the initial diagnosis; and those who had been partially restricted. This latter category included 16 children who either took a restricted quantity of gluten daily or who had
TABLE IV

44 Children Followed for 8-19 Years

\begin{tabular}{l|c|c|c}
\hline & \multicolumn{2}{|c|}{ Restriction of Gluten } \\
\cline { 2 - 3 } & Total & Partial & None \\
& 20 & 16 & 8 \\
\hline No complications & 20 & 5 & 0 \\
Height over 50th centile & 11 & 6 & $1(5<3$ rd $)$ \\
Diarrhoeal relapse & 0 & 11 & 8 \\
Megaloblastic anaemia & 0 & 2 & 3 \\
Dermatitis herpetiformis & 0 & 0 & 2 \\
Pregnancy & 1 Normal & 2 Normal & 1 Not \\
& & 1 Crisis & delivered \\
\hline
\end{tabular}

resumed a normal diet after a long period of gluten withdrawal previously. All the 20 children who kept to a strict diet gained and grew normally and had no complications. All 8 children who had had no restriction of diet had one or more complication and only 1 attained a height above the 50th centile, 5 being below the $3 \mathrm{rd}$. 8 had a diarrhoeal
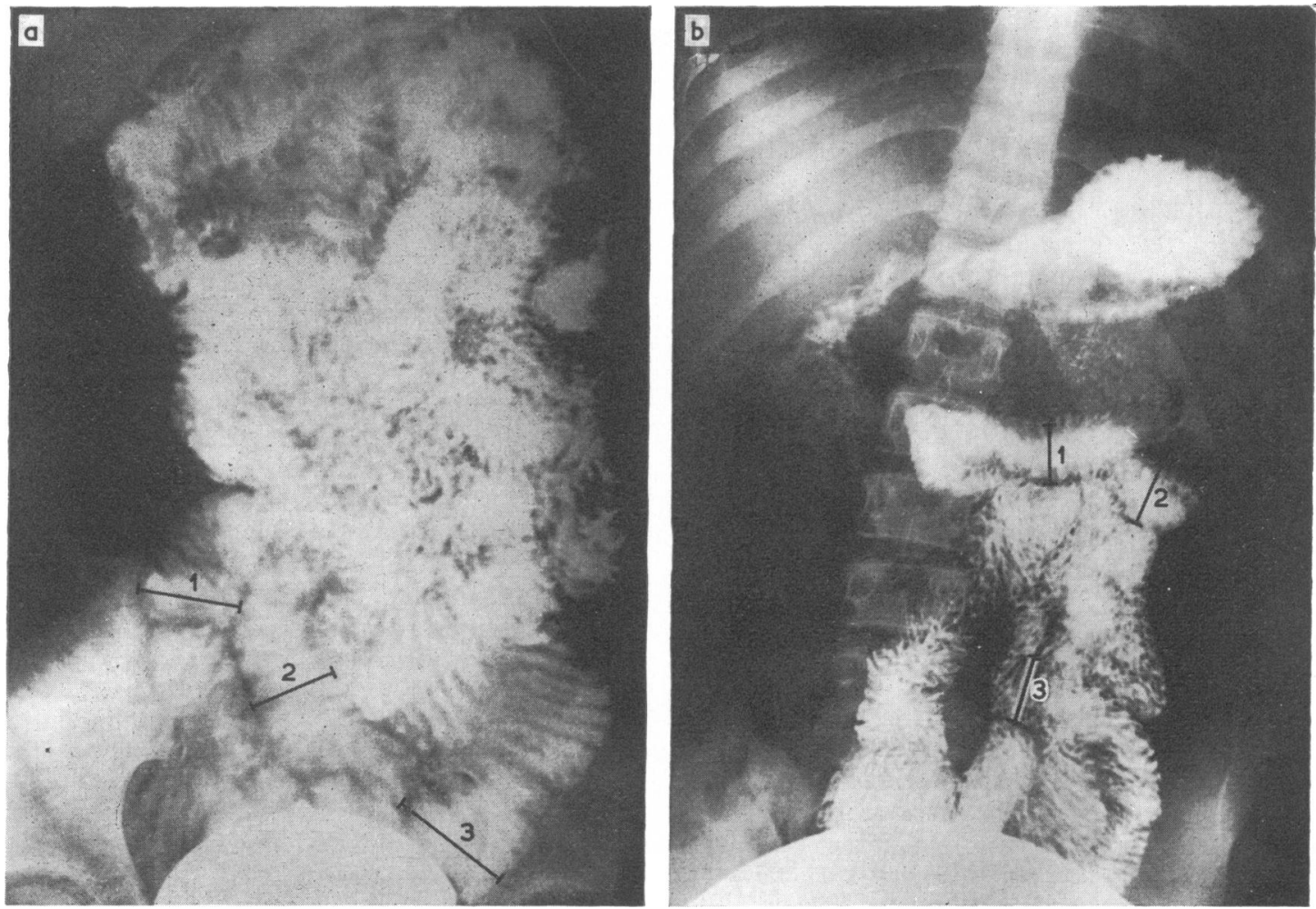

Fig. 14a.-Barium meal showing symptomless small bowel dilatation (average calibre 36 mm). C.H. aged 12 years 10 months,-gluten-free diet had lapsed for 10 months. b.-Barium meal in the same child 1 year and 10 months later, showing normal small bowel (average calibre $23 \mathrm{~mm}$ )—on a gluten-free diet. 
relapse, 3 developed megaloblastic anaemia, and 2 had dermatitis herpetiformis. Of the 16 children who had been on a partial diet, 11 had diarrhoeal relapses, and 2 megaloblastic anaemia. There were 3 normal pregnancies but 1 girl who had abandoned the diet for the previous 5 years developed a diarrhoeal crisis during pregnancy.

\section{Discussion}

Diagnosis. Long-term dietary control can only be justified if the diagnosis has been proved beyond doubt, and therefore jejunal biopsy is desirable in every case. For many reasons this ideal cannot always be achieved. Villous atrophy was found in 97 of the cases included in the series and the diagnosis was strengthened by a complete recovery of health after a long-term withdrawal of gluten and the fact that, sooner or later, a relapse occurred on its reintroduction.

The diagnosis of 13 cases who had never had confirmatory biopsy evidence rests on clinical, laboratory, and $x$-ray data, indicative of a malabsorption syndrome coupled with a recovery of health on a gluten-free diet. 11 children relapsed on returning to a gluten-containing diet. 2 children have remained on a strict diet.

In 1960 when biopsies first became generally available, 63 children had been diagnosed clinically and were curi ently being treated for coeliac disease. 5 of these $(8 \%)$ were found to have normal biopsies despite serious lapses in diet. This incidence of mistaken diagnosis compares closely with the figures quoted by Mortimer et al. (1968). They found that, of 10 adults previously diagnosed in childhood at The Hospital for Sick Children, Great Ormond Street, on a basis of clinical and laboratory data, 1 was not a coeliac. In the present series, 12 other cases referred with steatorrhoea proved to have normal biopsies. Their symptoms subsequently cleared up completely, the cause of them being left in doubt.

Gluten trials. When peroral biopsies were first introduced it was not fully realized that complete reversion of the pathological change could take place with treatment and 10 children who were tested after a long period of gluten withdrawal had normal biopsies. It is now our practice to perform biopsies preferably before, but in any case not later than 4 weeks after starting a glutenfree diet. Some degree of recovery will inevitably have taken place in the mucosa if treatment has begun, and minimal changes may be missed unless the specimen is examined by an experienced observer. Though the 10 children had fully recovered on a gluten-free diet, the diagnosis had not been confirmed and it was decided to challenge them with a course of gluten and repeat the biopsy. The children remained on a gluten-free diet, and $20 \mathrm{~g}$ gluten powder was sprinkled over their food to induce changes in the mucosa. This method was preferable to allowing unlimited glutencontaining foods such as bread, biscuits, and cakes because the child's taste for these foods was renewed so that subsequent withdrawal was resented. One child had 3 slices of bread daily in place of the powder.

Two other children were also included in the trials, one of whom had had no biopsy and one in whom the biopsy had failed. It has been shown that prolonged administration of gluten in normal subjects produces no changes in the small bowel mucosa (Levine et al., 1966).

Table $\mathrm{V}$ shows that symptoms developed in 9 children after periods lasting between 25 to 75 days, and biopsies taken during these times showed

TABLE V

Gluten Trials in 12 Children

\begin{tabular}{|c|c|c|c|c|}
\hline \multirow{2}{*}{$\begin{array}{c}\text { Type } \\
\text { of } \\
\text { Stress }\end{array}$} & \multirow{2}{*}{ No. } & \multirow{2}{*}{$\begin{array}{l}\text { Years } \\
\text { on } \\
\text { Diet }\end{array}$} & \multicolumn{2}{|c|}{ Villous Atrophy } \\
\hline & & & Number & Time (dy) \\
\hline $\begin{array}{l}\text { Gluten } \\
20 \mathrm{~g}\end{array}$ & 9 & $5-12$ & $\begin{array}{c}8 \text { positive } \\
1 \text { failed biopsy }\end{array}$ & $25-75$ \\
\hline Bread & 1 & 5 & 1 & 109 \\
\hline $\begin{array}{l}\text { Gluten and } \\
\text { bread }\end{array}$ & 2 & 11 & $\begin{array}{l}\text { (a) Negative at } \\
\text { Negative at } \\
\text { Positive at } \\
\text { (b) Negative at } \\
\text { Negative at }\end{array}$ & $\begin{array}{r}49 \\
365 \\
487 \\
203 \\
707\end{array}$ \\
\hline
\end{tabular}

complete villous atrophy in 6 and partial atrophy in 2 . One biopsy failed but severe symptoms of pain, vomiting, and anorexia which had developed, coupled with the presence of steatorrhoea, left little doubt of the diagnosis. Symptoms did not occur until 109 days in the girl taking bread and her biopsy then showed complete villous atrophy. The 2 children who were tested with gluten powder as well as bread are worthy of consideration because of the long periods of tolerance to gluten in each case. The girl eventually developed symptoms and villous atrophy after 16 months, though these changes were not apparent 4 months previously. The boy investigated over a period of 2 years failed to develop any evidence of coeliac disease. Unfortunately, he has since emigrated and further follow-up is impossible so he has been excluded 
from the series. One of us (W.F.Y.) had known him during his initial illness and was convinced, on clinical grounds, that he had coeliac disease. She was reluctant to give up the diagnosis, especially as he had a brother and nephew both of whom had proven coeliac disease. If an immunological basis for coeliac disease is accepted then the response to gluten may well be variable. It may even be possible that the long period (11 years) of strict dietary treatment resulted in a complete immunological remission and that a prolonged insult with gluten was necessary in such a case to provoke a response.

The patient who took small amounts of bread daily instead of gluten powder had minimal antigen and consequently a low level of antibody might account for the slower response to gluten.

Jejunal biopsy. Jejunal biopsy is not a technique to be embarked upon lightly and we agree with Anderson (1966) that, 'It should be carried out by persons who are in a situation to gain experience and to continue that experience'. With this in mind, only 3 people have been supervising small bowel biopsies in this hospital over the past 8 years and, so far, all children selected for biopsy have been over 7 months of age and weighing $7 \mathrm{~kg}$ or more and have shown no more than minimal small bowel dilatation confirmed by straight $x$ ray if necessary.

Complications include massive haemorrhage (Vidinli and Finlay, 1964) and perforation of the bowel, sometimes fatal (Shackleton and Haas, 1962). In a review of the diagnostic usefulness of peroral biopsy, Rubin and Dobbins (1965) pointed out that, of 15 perforations, more than one-third were in children. Partin and Schubert (1966) reported 6 perforations occurring in 83 biopsies from 51 children. All the perforations occurred in children weighing less than $10 \mathrm{~kg}$ and the authors thought that the physiological state of the children and the pathological thinness of the gut contributed to the results. Sheldon and Tempany (1966) concluded from their series of biopsies that the procedure was not justified as a routine investigation in coeliac disease on account of the risks of complications and also because of a high rate of failure in children. Notwithstanding such gloomy reports, there are many centres where jejunal biopsies are carried out with a high degree of safety. Kauder and Bayless (1964) and Hamilton (1966) performed biopsies on 60 and 42 children respectively without complications. Anderson (1966), in over 200 biopsies, had only 1 perforation. McNeish (1967) biopsied 96 children with no complications. The only one we have encountered in over 250 biopsies was incomplete severance of the mucosa in 1 case leading to 'hanging up' of the capsule which, however, was subsequently retrieved without incident after 24 hours.

Investigations. We agree with Anderson (1966) and Hamilton, Lynch, and Reilly (1969) that quantitative determination of fat excretion cannot be replaced by any of the other more modern tests of absorption. In the earlier part of the series detection of fat globules by microscopy of the stool replaced a fat balance in children unfit for this investigation. Now, however, it is usually possible to obtain an accurate stool collection for a minimum period of 3 days. The results of stool analysis are interpreted with due regard to the amount and type of fat intake and the patient's age. Additional information about the absorptive capacity of the bowel was always obtained by a measurement of the wet and dry weights of the daily stool, and compared with the normal results quoted by Andersen (1947). An increased bulk might lend weight to an equivocal fat finding.

Nearly all the $\mathrm{Hb}$ levels fell within the first few months of treatment in the younger age group, and this suggests that iron should be given to all children at this time. In any case, it is advisable to check the blood picture frequently in the early stages of recovery.

The serum protein level is an important indication of the severity of the disease. Andersen and di Sant' Agnese (1953) stated that 'coeliac crises' with sudden dehydration and acidosis did not occur as long as the serum protein level remains normal. A level below $5.0 \mathrm{~g} / 100 \mathrm{ml}$ indicates an unstable balance which can easily be upset by an intercurrent upper respiratory or other infection. In their series, serum protein levels were performed in 22 children shortly before or after crises, and levels below $5.5 \mathrm{~g} / 100 \mathrm{ml}$ were found in all. In this series as described earlier, 6 children had been driven into crisis by 'forced' feeding for a fat balance and all showed a serum protein level below $5 \cdot 5 \mathrm{~g} / 100 \mathrm{ml}$.

Serum folate estimations were only undertaken late in the series, but 12 out of the 14 children tested were low. McNeish and Willoughby (1969) reported that, of 30 children diagnosed by jejunal biopsy, all had a whole blood folate of less than 50 $\mathrm{ng} / \mathrm{ml}$, while 20 children with normal biopsies had levels greater than $60 \mathrm{ng} / \mathrm{ml}$. Exceptions to such findings bave already been published (Cook et al., 1970).

The radiological examination of the bowel in 
children with malabsorption syndromes has been shown to be helpful for diagnosis and also for detection of recurrences in patients already diagnosed as cases of gluten enteropathy who have alimentary dysfunction but no clinical manifestations of malabsorption (Haworth et al., 1968). Such patients are usually older children who have abandoned their diet. It was found that whenever a child had lost his abdominal distension in response to a previously strict diet. the development of strong abdominal musculature prevented the recurrence of abdominal distension as the bowel again became dilated during an episode of malabsorption. In these cases a single $x$-ray film of the jejunum (as described) taken at infrequent intervals provides a reliable alternative to collection and analysis of the faeces as a pointer to recurrence of malabsorption from gluten before the onset of clinical manifestations. Such a small and infrequent amount of radiation is considered justified by the information it provides on the patient's health.

Follow-up. In children complete recovery of the histology of the mucosa on withdrawal of gluten is to be expected and, once this has taken place, absorption becomes normal. After the early months of treatment, therefore, there is no need for vitamin supplements but iron may be required for up to a year since children are growing rapidly during this phase. Sufficient protein must be taken to make up for that extracted from the flour.

Table IV pinpoints the value of remaining on a gluten-free diet. From our experience normal alimentary function cannot be assumed when a patient is symptom free and it must be emphasized that subclinical relapses as seen in older children are often silent and may exist for years. The most noticeable effect is on growth, which often ceases altogether, but iron and folic acid deficiency are common. Though it is easy to prescribe these substances and maintain a normal haematological picture, the malabsorption of minerals and other essentials must also be considered. Nearly every child in our series showed decreased density of the bones radiologically but only 2 children had overt rickets. This complication developed after a period of partial treatment and was not seen in any child at the initial episode.

Convincing evidence of a relapse cannot be obtained by demonstration of steatorrhoea in a teenager, who is usually unwilling to co-operate in the stool collection, and the diagnosis therefore rests on delayed growth, a low serum iron and folate, and, sooner or later, the development of small bowel dilatation detectable by $x$-ray examination.

If the subclinical relapse continues through the prepubertal years, the adolescent growth spurt is not entirely annulled and may be similar to the normal, so that the adult height attained is sometimes greater than expected. However, these patients remain at risk and may easily break down under stress, such as pregnancy, as shown by 1 girl in the series who abandoned treatment after 5 years, aged 13 years, and then continued on a normal diet for a further 5 years. She claimed to be symptom free and remained clinically well. During pregnancy, however, she relapsed with severe diarrhoea and megaloblastic anaemia. Despite treatment with folic acid, vitamin $\mathrm{B}_{12}$, and a glutenfree diet, she has never really recovered her full health 4 years later. If minor signs of malabsorption are ignored until more serious ill health developing in later years makes treatment imperative, the chance of complete recovery may be missed, since it is well recognized that adults respond to treatment less readily and completely than children. To some extent this is borne out by our own findings when comparing the response to treatment in the younger and older age groups. French, Hawkins, and Smith (1957) examined 22 untreated patients with a long history, whose ages ranged from 21 to 59 years at the time of examination and found that 16 regained full health after treatment with glutenfree diet, with or without the addition of folic acid and vitamin $B_{12}$. The remaining 6 patients failed to recover with gluten-free diet, though there was some improvement.

Conclusion. In view of the foregoing, it cannot be emphasized too strongly that, no matter how well a child may feel on a normal diet, he should always be advised to return to a strict gluten-free diet and adhere to it. For many years we have been of the opinion that dietary treatment should be continued until growth is completed and the need for this counsel has been borne out by the optimal growth and health achieved by the 20 children who did not deviate from a strict diet, and the high incidence of complications and depressed growth in those who did (Table IV). Other workers have found a similar pattern in adolescence and early adult life. Mortimer et al. (1968) found that all her 9 cases required treatment at follow-up and in Sheldon's cases (1969) only $25 \%$ of 57 young adults off diet were healthy. In view of the inevitability of relapse sooner or later in the majority of patients once treatment is abandoned, we are in complete agreement with Sheldon that a gluten-free diet 
should be maintained for life. In this view we are further supported by the evidence of Harris et al. (1967) that a gluten-free diet appears to decrease the risk of malignant complications.

The authors are grateful to the Consultant Staff of the Queen Elizabeth Hospital for Children, who permitted them to study their cases, to Professor C. C. Booth, Royal Postgraduate Medical School, Hammersmith Hospital, for making the adolescent follow-up records available for study, and to Dr. P. E. Mortimer, Consultant Paediatrician to Chase Farm Hospital, for all her help. The work was supported by a part-time grant for E.M.P. from the Heinz Fellowship in Gastroenterology. We wish to acknowledge Mr. L. T. Clifford's assistance with the preparation of the figures and the photographs of the films.

\section{REFERENCES}

Andersen, D. H. (1947). Celiac syndrome. VI. The relationship of celiac disease, starch intolerance, and steatorrhea. Fournal of Pediatrics, 30, 564.

Andersen, D. H., and di Sant' Agnese, P. A. (1953). Idiopathic celiac disease. 1. Mode of onset and diagnosis. Pediatrics, 11, 207.

Anderson, C. M. (1966). Intestinal malabsorption in childhood. Archives of Disease in Childhood, 41, 571.

Arthur, A. B., Clayton, B. E., Cottom, D. G., Seakins, J. W. T., and Platt, J. W. (1966). Importance of disaccharide intolerance in the treatment of coeliac disease. Lancet, 1, 172.

Baldwin, E. M., Clayton, B. E., Jenkins, P., Mitchell, J., and Renwick, A. G. C. (1962). Collection of urine and faeces in children with a note on fat balances. Archives of Disease in Childhood, 37, 488.

Booth, C. C., Stewart, J. S., Holmes, R., and Brackenbury, W. (1962). Dissecting microscopic appearances of intestinal mucosa. In Intestinal Biopsy. Ciba Foundation Study Group No. 14, p. 2. Ed. by G. E. W. Wolstenholme and M. P. Cameron. Churchill, London; Little, Brown, Boston.

Burgess, E. A., Levin, B., Mahalanabis, D., and Tonge, R. E. (1964). Hereditary sucrose intolerance: levels of sucrase activity in jejunal mucosa. Archives of Disease in Childhood, 39, 431.

Cook, D. M., Evans, N., Lloyd, A., and Stewart, J. S. (1970). Normal serum and red-cell folate levels in a child with coeliac disease. Lancet, 1,571 .

Crosby, W. H., and Kugler, H. W. (1957). Intraluminal biopsy of the small intestine: the intestinal biopsy capsules. American Journal of Digestive Diseases, 2, 236.

Dicke, W. K. (1950). Coeliakie. Een onderzoek naar de nadelige invloed van sommige graansoorten op de lijder aan coeliakie. Thesis, Utrecht.

Dicke, W. K, Weijers, H. A., and van de Kamer, J. H. (1953). Coeliac disease. II. The presence in wheat of a factor having a deleterious effect in cases of coeliac disease. Acta Paediatrica, 42, 34.

French, J. M., Hawkins, C. F., and Smith, N. (1957). The effect of a wheat-gluten-free diet in adult idiopathic steatorrhoea. Quarterly fournal of Medicine, 26, 481.

Gee, S. (1888). On the coeliac affection. St. Bartholomew's Hospital Reports, 24, 17.

Hamilton, J. R. (1966). Risk of intestinal biopsy in infants. New England fournal of Medicine, 274, 521 .

Hamilton, J. R., Lynch, M. J., and Reilly, B. J. (1969). Active coeliac disease in childhood. Quarterly fournal of Medicine, 38, 135.

Harris, O. D., Cooke, W. T., Thompson, H., and Waterhouse, J. A. H. (1967). Malignancy in adult coeliac disease and idiopathic steatorrhoea. American fournal of Medicine, $42,899$.

Haworth, E. M., Hodson, C. J., Joyce, C. R. B., Pringle, E. M., Solimano, G., and Young, W. F. (1967). Radiological measurement of small bowel calibre in normal subjects according to age. Clinical Radiology, 18, 417 .
Haworth, E. M., Hodson, C. J., Pringle, E. M., and Young, W. F. (1968). The value of radiological investigations of the alimentary tract in children with the coeliac syndrome. Clinical Radiology, 19, 65.

van de Kamer, J. H., Huinink, H. ien Bokkel, and Weijers, H. A. (1949). Rapid method for the deternination of fat in feces. fournal of Biological Chemistry, 177, 347.

Kauder, F., and Bayless, T. M. (1964). Peroral intestinal biopsy in children: a technique. American fournal of Diseases of Children, 107, 582 .

Laws, J. W., Shawdon, H., Booth, C. C., and Stewart, J. S. (1963). Correlation of radiological and histological findings in idiopathic steatorrhoea. British Medical fournal, 1, 1311.

I.evin, B. (1969). Disorders of carbohydrate digestion and absorption. Journal of Clinical Pathology', 22, (Suppl. Ass. Clin. Path.), 2, 24.

Levin, B., Mackay, H. M. M., Neill, C. A., Oberholzer, V. G., and Whitehead, T. P. (1959). Weight gains, serum protein levels and health of breast fed and artificially fed infants, full-term and premature. Special Report Series, Medical Research Council, 296.

Levine, R. A., Briggs, G. W., Harding, R. S., and Nolte, L. B. (1966). Prolonged gluten administration in normal subjects. N'ew England fournal of Medicine, 274, 1109.

McNeish, A. S. (1967). Jejunal biopsies in infants and underweight children. Archives of Disease in Childhood, 42, 623.

McNeish, A. S., and Willoughby, M. L. N. (1969). Whole-blood folate as a screening test for coeliac disease in childhood. Lancet, 1, 442.

Medical Research Council, Committee on Haemoglobin Surveys. (1945). Haemoglobin levels in Great Britain in 1943 (with observations upon serum protein levels). Special Report Series, Medical Research Council, 252.

Mortimer, P. E., Stewart, J. S., Norman, A. P., and Booth, C. C. (1968). Follow-up study of coeliac disease. British Medical Fournal, 3, 7 .

Parsons, L. G. (1932). Celiac disease. American fournal of Diseases of Children, 43, 1293.

Partin, J. C., and Schubert, W. K. (1966). Precautionary note on the use of intestinal-biopsy capsule in infants and emaciated children. New England Fournal of Medicine, 274, 94.

Paulley, J. W. (1954). Observations on the aetiology of idiopathic steatorrhoea: iejunal and lymph-node biopsies. British Medical fournal, 2, 1318.

Read, A. E., Gough, K R., Bones, J. A., and McCarthy, C. F. (1962). An improvement to the Crosby peroral intestinal biopsy capsule. Laniet, 1, 894.

Rubin, C. E., and Dobbins, W. O., III (1965). Peroral biopsy of the small intestine. A review of its diagnostic usefulness. Gastroenterology, 49, 676.

Sakula. J., and Shiner, M. (1957). Coeliac disease with atrophy of the small-intestine mucosa. Lancet, 2, 876.

Shackleton, J., and Haas, L. (1962). Fatal peritonitis after jejurıal biopsy with the Crosby capsule. Lancet, 2, 989.

Sheldon, W. (1949). Coeliac disease: a relation between dietary starch and fat absorption. Archives of Disease in Childhood, 24, 81.

Sheldon. W. (1969). Prognosis in early adult life of coelia: children treated with a gluten-free diet. British Medical fournal, 2, 401

Sheldon, W., and Tempany, E. (1966). Small intesline peroral biopsy in coeliac children. Gut, 7, 481 .

Shiner, M. (1956a). Duodenal biopsy. Lancet, 1, 17.

Shiner M (1956b). Jejunal-biopsy tube. Lancet, 1, 85

Still, G. F. (1918). The Lumleian lectures on coeliac disease. Lancet, 2, 163, 193, and 227.

Tanner, J. M. (1958). The evaluation of physical growth and development. In Modern Trends in Paediatrics, (2nd series), p. 325. Ed. by A. Holzel and J. P. M. Tizard. Butterworth, London.

Vidinli, M., and Finlay, J. M. (1964). Massive hemorrhage following small bowel biopsy. Canadian Medical Association fournal, 91, 1223.

Correspondence to Dr. E. M. Pringle, The Queen Elizabeth Hospital for Children, Hackney Road, London E2 8PS. 